\begin{tabular}{|c|c|c|}
\hline 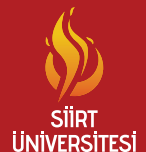 & $\begin{array}{c}\text { Türkiye Tarımsal Araştırmalar Dergisi } \\
\text { dergipark.org.tr/tutad }\end{array}$ & $\begin{array}{l}\text { Turk J Agric Res } \\
\text { 2019, 6(3): 295-307 } \\
\text { ○ TÜTAD } \\
\text { ISSN: 2148-2306 } \\
\text { e-ISSN: 2528-858X }\end{array}$ \\
\hline Bilimin Psüunda & Araştırma Makalesi / Research Article & doi: 10.19159/tutad.603503 \\
\hline
\end{tabular}

\title{
Çok Kriterli Karar Verme Analizine Dayalı Tarımsal Amaçlı Arazi Kalite İndisi Uygulaması
}

\author{
Mert DEDEOĞLU ${ }^{1 *}$, Levent BAŞAYIĞİiT ${ }^{2}$, Mahmut YÜKSEL ${ }^{3}$ \\ ${ }^{1}$ Selçuk Üniversitesi, Ziraat Fakültesi, Toprak Bilimi ve Bitki Besleme Bölümü, Konya, TÜRKİYE \\ ${ }^{2}$ Isparta Uygulamalı Bilimler Üniversitesi, Tartm Bilimleri ve Teknolojileri Fakültesi, Toprak Bilimi ve Bitki Besleme Bölümü, Isparta, \\ TÜRKIYYE \\ ${ }^{3}$ Ankara Üniversitesi, Ziraat Fakültesi, Toprak Bilimi ve Bitki Besleme Bölümü, Ankara, TÜRKIYE
}

\begin{tabular}{|c|c|}
\hline Geliş Tarihi/Received: 07.08.2019 & Kabul Tarihi/Accepted: 22.10 .2019 \\
\hline \multicolumn{2}{|l|}{ ORCID ID (Yazar surasina göre / by author order) } \\
\hline (D)orcid.org/0000-0001-8611-3724 (Dorcid.org/0000-0003-24 & cid.org/0000-0002-5001-2048 \\
\hline
\end{tabular}

Sorumlu Yazar/Corresponding Author: mdedeoglu@selcuk.edu.tr

Öz: Bu çalışmanın amacı bölgeye özgün olarak uzman görüşü ve çok kriterli karar destek yaklaşımlarına dayalı bir arazi kalite indisi (AKİ) geliştirmek ve tarım arazilerinde uygulamaktır. Çalışma, Akdeniz iklim ekolojisini temsilen 3338.61 hektar büyüklügünndeki Muğla-Dalaman Tarım İşletme Genel Müdürlüğü arazilerine ait 7 toprak serisi ve 43 fazında yürütülmüştür. Araştırmada bölge arazilerini ve toprak özelliklerinin bir veya daha fazlasını temsil etme niteliğine sahip toplam 13 indikatör; i) Arazi: derinlik, eğim, taşlık ve drenaj, ii) Fiziksel: faydalı su kapasitesi, hacim ağırlığı, tekstür, iii) Kimyasal: elektriksel iletkenlik (EC), pH, organik madde, fosfor, potasyum, toplam azot olmak üzere uzman görüşü ve literatür bilgisi 1şı̆ı̆ında seçilmiştir. İndikatörlerin ikili karşılaştırmasında çok kriterli karar destek yaklaşımı olan Analitik Hiyerarşik Süreç metodu kullanılmıştır. Araştırmada, AKİ değerlendirmesi sonucu işletme arazilerinin \% 61.56'sı "çok yüksek" ve "yüksek" kaliteli olarak sınıflandırılmış, \% 35.29 büyüklüğünde arazinin tarımsal kalite sınıfı "düşük" ve "çok düşük" nitelikte belirlenmiş ve coğrafi bilgi sistemi ortamında haritalanmıştır. Çalışma ile bölge arazilerinin kalite son indis değerini derinlik (\% 12.5), eğim (\% 12), EC (\% 11.1) ve bünye (\% 10.7) indikatörlerinin yüksek oranda ağırlık katsayıları ile etkilediği belirlenmiştir. Aynı zamanda tarımsal açıdan düşük kalite değerlerine sahip arazilerde bazı iyileştirme tedbirlerinin (drenaj kanallarının geliştirilmesi organik madde ilavesi, taş toplama) alınması ile yüksek kalite sınıflarına ulaşabileceği önerilmiştir.

Anahtar Kelimeler: Analitik hiyerarşik süreç, arazi kalite indisi, uzman bilgisi, toprak serisi, toprak haritalama

\section{Application of Agricultural Land Quality Index Based on Multi Criteria Decision Analysis}

\begin{abstract}
The aim of this study is to develop a land quality index (LQI) based on expert opinion and multi criteria decision support approaches specific to the region and to apply it on agricultural lands. The study was carried out in 7 soil series and 43 land units of Muğla-Dalaman General Directorate of Agriculture Management with an area of 3338.61 ha, representing Mediterranean climate ecology. In this study, 13 indicators; I) Land: soil depth, slope, stoniness and drainage, ii) Physical: available water capacity, bulk density, texture, iii) Chemical: $\mathrm{pH}$, electrical conductivity (EC), organic matter content, phosphors, potassium, and total nitrogen which are representative of one or more of the land and soil characteristics were selected in the light of expert and literature knowledge. Analytical Hierarchy Process which is a multi-criteria decision approach was used for pairwise comparisons of the indicators. As a result of the LQI assessment, $61.56 \%$ of the farmland was classified as "very high" and "high" quality and the agricultural quality class of the $35.29 \%$ of the land was determined as "low" and "very low" quality and mapped in a geographical information system environment. According to obtained results it was determined that the final quality index values of the lands were affected by depth (12.5\%), slope (12\%), EC (11.1\%) and texture (10.7\%) indicators with high weight coefficients. In addition, it has been suggested that areas with low agricultural quality values can reach to high-quality classes with some improvement measures (development of drainage channels, the addition of organic material, removal of stones).
\end{abstract}

Keywords: Analytical hierarchy process, land quality index, expert knowledge, soil series, soil mapping 


\section{Giriș}

Sürdürülebilir tarımsal üretim, gelişmiş veya gelişmekte olan ülkelerin tarımsal politikalarının en önemli hedefidir (Kumar ve Jhariya, 2015). Bu doğrultuda, toprağı yönetimsel talepleri ile dengelemek ve kaynak kullanımını optimize ederek uzun vadeli verimliliği sağlamak amaçlanmaktadır (Joshua ve ark., 2013). Bu amaç ve hedeflere ulaşmak için sürdürülebilir tarımsal uygulamaların planlanmasında arazi kalitesinin belirlenmesi, toprak bilimciler tarafindan önemli ekolojik yaklaşımlardan biri olmuştur (Xue ve ark., 2019). Arazi kalitesi belli bir ekosistem içinde yer alan toprağın doğasından kaynaklanan ve belli bir yönetim altındaki kullanımına bağlı olarak ortaya çıkan fonksiyonlarının kapasitesi olarak tanımlanmaktadır (Karlen ve ark., 2014). Arazi kalitesinin belirlenmesinde, kalitatif veya yarı kantitatif görsel yaklaşımlardan (Dengiz ve Başkan, 2009; Shepherd, 2009; Mueller ve ark., 2010), laboratuvar analizlerine ve morfolojik ölçümlerin matematiksel fonksiyonlarına dayanan kantitatif indekslere kadar birçok yöntem geliştirilmiştir (Karlen ve ark., 2014; Askari ve Holden, 2014).

Genel olarak farklı birimlere sahip toprak özelliklerinin birbiri ile ilişkilendirilmesi gibi karmaşık analiz gerektiren uygulamaların çözümlerinde indeksleme teknikleri yaygın bir şekilde kullanılmakta olup (Rahmanipour ve ark., 2014), bunlara uzman görüşünü de içinde barındıran çok kriterli karar destek yaklaşımları ve coğrafi bilgi sistemleri (CBS) entegrasyonunun dahil olması ile yüksek doğrulukla arazi kalitesini ölçebilen modeller geliştirilmektedir (Ying ve ark., 2007; Veisi ve ark., 2016). Bu amaçla, Çok Kriterli Karar Verme Analizi olan Analitik Hiyerarşik Süreç (AHS) (Saaty, 1980), çoklu- heterojen faktörlerin değerlendirilmesinde tercih edilmektedir (Ceballos ve López, 2003; Malczewski, 2006; Mandere ve ark., 2010; Akıncı ve ark., 2013; Dengiz ve Sarığlu, 2013; Dengiz ve Özyazıc1, 2018). Arazi kalite indeksi (AKI) genellikle dört aşamalı bir süreç kullanılarak geliştirilmektedir. $\mathrm{Bu}$ aşamalar; (1) indikatör seçimi, (2) indikatör kategorizasyonu ve puanlama, (3) göstergelerin önem seviyesine göre ağırlıklandırılması ve (4) puanların seçilen bir modele göre hesaplanmasıdır (Andrews ve ark., 2004; Askari ve Holden 2014; Dengiz ve ark., 2015; Xue ve ark., 2019). Ancak geliştirilen arazi kalite indeksleri sınırlı bir ölçekte, belirli amaçlar ve çevresel koşullar altında genellikle geçerlidir (Imaz ve ark., 2010). Bu nedenle her türlü coğrafyaya uygun ve evrensel olarak kullanılabilen bir AKİ bulunmamaktadır (Zhang ve ark., 2015). Nitekim tüm coğrafyalar için arazi ve toprak özellikleri, kullanım tipi ve bitki türleri için arazi kalitesini belirleyebilen indislerin mevcut olması beklenemez (Bydekerke ve ark., 1998; Store ve Kangas, 2001). Aynı zamanda tüm ekolojik değişkenleri ve sosyokültürel alışkanlıkları temsil edebilecek bir modelin geliştirilmesi pratikte mümkün olmayıp; teoride zaman, iş gücü ve maliyeti yönünden ekonomik değildir (Doran ve Parkin, 1996). Bu nedenle Türkiye'de de farklı yönetim sistemleri ve farklı ekolojik koşullar altındaki tarım arazilerinin kalitesinin belirlenmesine yönelik çalışmalar uzman görüşü işığında yapılmalıdır. Çalıșma ile Akdeniz iklim özelliğine ve benzer ekolojilerde uygulanabilir bir arazi kalite indeksinin uzman görüşü ve Analitik Hiyerarşik Süreç (AHS) yaklaşımları kullanılarak geliştirilmesi ve Tarım İşletmeleri Genel Müdürlüğü’ne bağlı MuğlaDalaman Tarım İşletme Müdürlüğü arazilerinin kalite skorlaması yapılarak CBS ortamında haritalanması amaçlanmıştır.

\section{Materyal ve Yöntem}

\subsection{Materyal}

Çalışma, Muğla ili sınırları içerisinde, $36^{\circ} 42^{\prime}$ $11^{\prime \prime}-36^{\circ} 48^{\prime} 44^{\prime \prime}$ kuzey enlemleri, $28^{\circ} 43^{\prime} 25^{\prime \prime}-28^{\circ}$ 48'52" doğu boylamları arasında yer Dalaman Tarım İşletme Müdürlüğü arazilerinde yürütülmüştür. Çalışma alanı lokasyon haritası ve toprak serilerinin dağılımları Şekil 1'de sunulmuştur. Kuzeyde Sandıras Dağları, batıda Dalaman Çayı, doğuda Tersakan Deresi ve güneyde Akdeniz'e birleşen işletme arazilerinin denizden yüksekliği 1-7 metre arasındadır. İşletmede; tarım arazisi büyüklüğü 2.687 hektar olup, bu araziler tarla bitkileri ( $\%$ 48), bahçe bitkileri (\% 32), yem bitkileri ( $\%$ 18) ve tabii mera ( $\%$ 3) olarak ayrılmaktadır. İşletmenin toplam arazi varlığ 3338.61 hektardır.

Dalaman Devlet Üretme Çiftliği'ndeki en önemli jeolojik formasyon, Dalaman Çayı'nın Halosen ve Pleistosen'deki aktivitesi sonucu oluşan alüviyal yelpazedir. Çiftliğin kuzey batısında ise ofiyolitlerden oluşan yükseltiler yer almaktadır (Bilgin ve ark., 1997). Ancak bunlar çiftlikte küçük bir alanı kaplamaktadır.

Bölgede kışları 1lık ve yağışlı, yazları sıcak ve kurak olan tipik Akdeniz iklimi etkilidir. Meteoroloji Genel Müdürlüğü, Dalaman Meteoroloji Gözlem İstasyonu (Anonim, 2014) uzun yillar (1960-2012) ortalama iklim verilerine göre yıllık yağış miktarı $1152 \mathrm{~mm}$, ortalama sicaklık $15{ }^{\circ} \mathrm{C}$, en sicak ay $26.3{ }^{\circ} \mathrm{C}$ ile Temmuz, en soğuk ay ise $1.5^{\circ} \mathrm{C}$ ortalama ile Ocak ayıdır. En yağışlı ay Aralık (272.9 mm), en az yağışlı ay ise Temmuz $(7.0 \mathrm{~mm})$ ayıdır. Toprak Taksonomisi (Anonymous, 1999)'ne göre değerlendirilen iklim verileri ile çalışma alanının toprak nem rejimi Xeric 


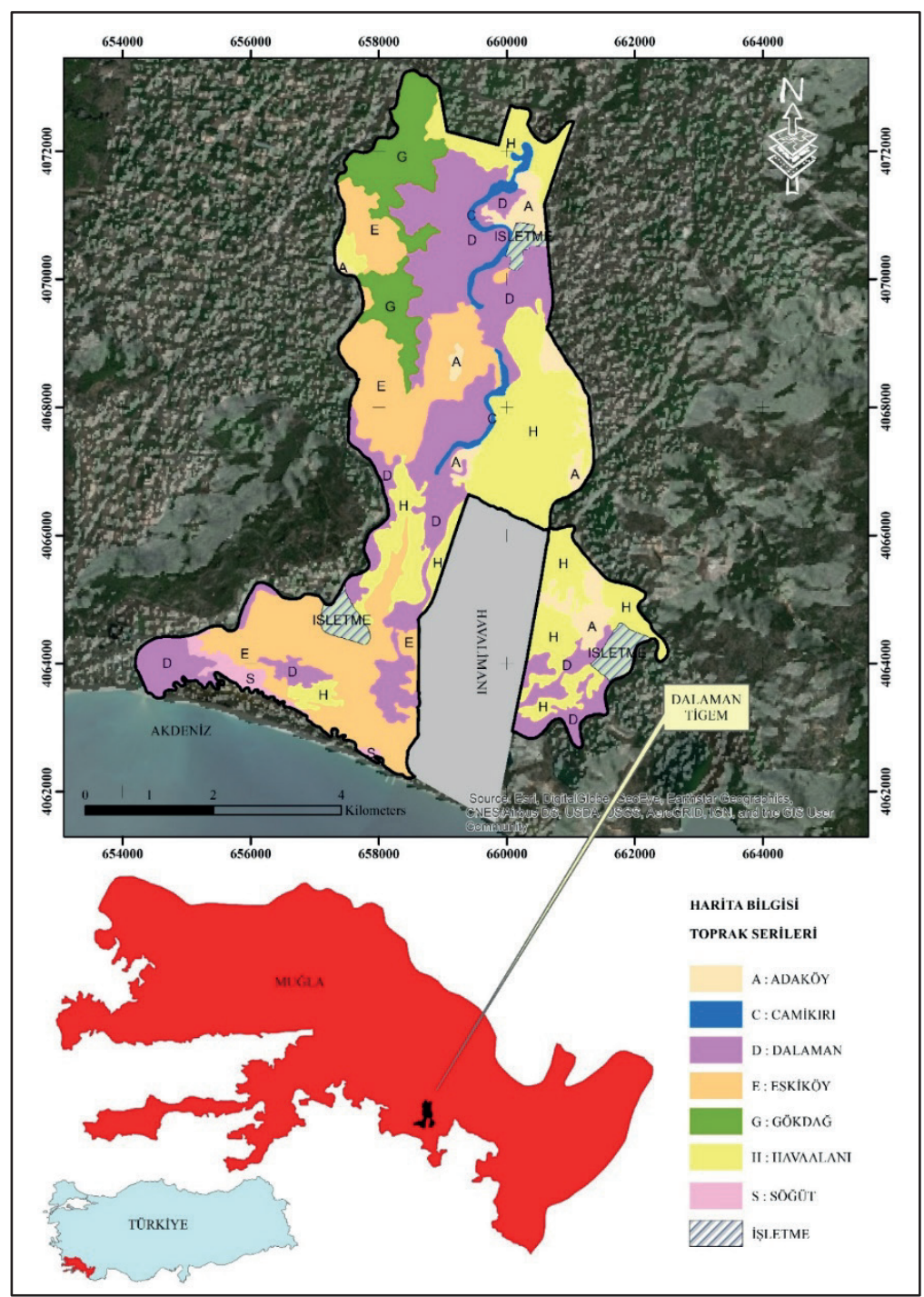

Şekil 1. Çalışma alanının coğrafi konumu ve toprak seri dağılım haritası

ve toprak sicaklık rejimi Thermic olarak belirlenmiştir.

Çalışmada; Dalaman Devlet Üretme Çiftliği Toprak Etüd Raporu ve Haritası (Anonim, 1982)'nda belirtilen toprak serilerinin faz ayırımları (derinlik, tekstür, eğim, taşlık, drenaj, vb.) ve alansal dağılımları kullanılmıştır. $\mathrm{Bu}$ sayede haritalama birimi düzeyinde arazi kalite değerlendirmeleri yapılmıştır. Çalışma alanı toprakları Anonymous (1999)'a göre 7 farklı seride, 43 haritalama biriminde Typic Xerofluvent, Mollic Xerofluvent, Aquic Xerofluvent ve Lithic Xeroorhent alt gruplarında sınıflandırılmıştır (Tablo 1).

Araştırma ile önceden tanımlanan toprak serilerinin kontrolü için her bir seriyi temsil eden 6 farklı profil çukurları kazılmış, morfogenetik tanımlamalar yapılmış ve genetik horizon esasına göre 31 adet bozulmuş ve 15 adet bozulmamış toprak örnekleri alınmıştır. İşletmenin kuzeybatısında yer alan çok dik eğimlerde (>\% 12), çok sı̆̆ $(0-10 \mathrm{~cm})$ ve doğal bitki örtüsü ile kaplı Gökdağ Serisi üzerinde örnekleme yapılmamıştır. Arazide toprakların morfolojik özelliklerinin incelenmesi, örneklemeler ve laboratuvar analizleri Anonymous (2011)'a göre 2014 yılında yapılmıştır.

Tablo 1. Araştırma alanı (Dalaman) toprak serilerinin Anonymous (1999)'a göre sinıflandırması

\begin{tabular}{lc}
\hline Seri & Alt grup \\
\hline Dalaman & Typic Xerofluvent \\
Eskiköy & Typic Xerofluvent \\
Adaköy & Typic Xerofluvent \\
Havaalanı & Mollic Xerofluvent \\
Camikırı & Aquic Xerofluvent \\
Söğüt & Typic Xerofluvent \\
Gökdağ & Lithic Xeroorhent \\
\hline
\end{tabular}




\subsection{Yöntem}

\subsection{1. İndikatör seçimi, alt gruplara skorlama ve ağırlıklandırma}

Arazi kalitesini belirlemek için kullanılacak indikatörlerin seçimi çok önemlidir (Zhan ve ark., 2016). Zira farklı tarımsal kullanımlar altında bulunan arazilerin kalitesini, değișen miktarlarda etkileyen birçok özellik vardır ve bunların hepsini kullanmak mümkün değildir. Bununla ilgili olarak Doran ve Parkin (1996), modelsel yaklaşımlarda mümkün olduğunca az parametrenin kullanılmasını önermişlerdir. Nitekim bazı fiziksel, kimyasal ve biyolojik özelliklerin arasında yüksek korelasyon olduğu bilinmekte, hepsinin aynı anda indikatör olarak kullanılmasının pratik olarak mümkün olmadığı gibi arazi değerlendirme ölçüm paradigmasının temel ilkelerine de aykırı olduğu belirtilmektedir (Andrews ve ark., 2004). Bu konudaki bir diğer husus ise; çok fazla toprak analizi yapmak, geliştirilecek indeksin uygulamasını da hantallaştırmaktadır (Askari ve Holden, 2014). Bu nedenle çalışmada kullanılan indikatörlerin toprak özelliklerinden bir veya daha fazlasını temsil etme niteliği de dikkate alınarak; tarımsal amaçlı arazi kalite indeksinde bitki gelişimini etkileyen ve Anonymous (1976), De La Rosa ve Van Diepen (2009), Huddleston ve ark. (1987), Barraclough (1989), McVay ve ark. (1989), Anonymous (1990), Anonymous (1999), Arshad ve Martin (2002), Topal ve ark. (2002), Gezgin ve Hamurcu (2006), Hazelton ve Murphy (2007), Iojă ve ark. (2014), Zhan ve ark. (2016), Mustafa ve ark. (2017), Aldababseh ve ark. (2018) tarafindan da bildirilen/kullanılan 13 farklı değerlendirme parametresi seçilmiştir. Arazi kalite indeksi için seçilen parametreler ve etkinlikleri Tablo 2'de sunulmuştur.

Tablo 2. Çalışmada gerçekleştirilen fiziko-kimyasal analizler ve yöntemleri

\begin{tabular}{|c|c|c|c|}
\hline Parametreler & Birim & Protokol & Kaynak \\
\hline Hacim ağırlı̆̆ 1 (HA) & $\mathrm{gr} \mathrm{cm}^{-3}$ & Bozulmamış toprak örneği & Blake ve Hartge (1986) \\
\hline Faydalı su & $\%$ & $\begin{array}{l}\text { Seramik tabla, basınç ünitesi, tarla } \\
\text { kapasitesi ve solma sontası fark1 } \\
(33 \mathrm{kPa}-1500 \mathrm{kPa})\end{array}$ & Klute (1986) \\
\hline Tekstür & $\%$ & Hidrometre yöntemi & Anonymous (2011) \\
\hline Organik madde (OM) & $\%$ & $\begin{array}{c}\text { Potasyum dikromat ile }\left(\mathrm{K}_{2} \mathrm{Cr}_{2} \mathrm{O}_{7}\right) \\
\text { oksidasyon yöntemi (Walkley-Black) }\end{array}$ & Nelson ve Sommers (1982) \\
\hline $\begin{array}{l}\mathrm{pH} \\
\text { Elektriksel İletkenlik (EC) }\end{array}$ & $\frac{1: 2.5}{\mathrm{dS} \mathrm{m} \mathrm{m}^{-1}}$ & Toprak-su süspansiyonu (w:v) & Anonymous (2011) \\
\hline Yarayışlı fosfor $(\mathrm{P})$ & $\mathrm{mg} \mathrm{kg}^{-1}$ & Olsen yöntemi & Olsen ve Sommers (1982) \\
\hline Toplam azot $(\mathrm{N})$ & $\%$ & Kjeldahl yöntemi & Bremner ve Mulvaney (1982) \\
\hline Yarayışlı potasyum $(\mathrm{K})$ & $\mathrm{mg} \mathrm{kg}^{-1}$ & $1 \mathrm{~N}$ amonyum asetat, flame fotometre & Kacar (2009) \\
\hline
\end{tabular}

Çalıșmada arazi indikatörleri bölge topraklarının etüt raporu ve haritasından CBS ortamında sayısal katmanlar olarak üretilmiştir. Diğer indikatör değerleri laboratuvar analizleri sonucu elde edilmiştir. Araştırmada yürütülen laboratuvar analizleri ve yöntemleri Tablo 3'te verilmiştir.

Arazi kalite indeksi parametrelerinin alt faktör puanlaması Tablo 4'te sunulmuştur. Ek olarak arazi indikatörlerinin seçiminde, detaylı toprak haritasında belirtilen ve bitki gelişimini kısıtlayıcı parametreler olarak nitelenen fazlar kullanılmış, besin elementi indikatörleri ise hem bitki gelişimine hem de çevresel etki faktörleri değerlendirilerek seçilmiş ve alt gruplara skorlanmıştır.

Çalışmada her bir indikatöre ait parametreler için 1 ile 4 arasında skor değerleri atanmıştır. Kriter sınıfları tarımsal yetiştiriciliğe imkân vermesi durumunda 4, imkân vermeyen durumda ise 1 değerini almaktadır. $\mathrm{Bu}$ iki değer arası ise sinırlandırıcı faktör ve derecesine göre değerlendirilmiștir. Çalıșmanın indikatörlerinin ikili karşılaştırmasında çok kriterli karar verme algoritması olan AHS metodu kullanılmıştır (Saaty, 2008). Bu metot, ele alınan parametrelerin ikili olarak karşılaştırılmasından elde edilen öncelik değerlerine dayalı bir ölçüm teorisidir ve en iyi karar alternatifinin seçilmesinde, hem kantitatif (objektif, nicel) ve hem de kalitatif (sübjektif, nitel) faktörlerin dikkate alınmasına imkân vermektedir (Romano ve ark., 2015). Çalışmada seçilen parametrelerin AHS metoduna göre geçerli bir şekilde ağırlıklandırılmasında;

- Parametrelerin etki durumu göz önünde bulundurularak İkili Karşılaştırma Matrislerinin oluşturulması,

- Matrisdeki her bir elemanın, bulunduğu sütunun toplam değerine bölünmesi ile Normalize Edilmiş İkili Karşılaştırmalar Matrisi dönüşümü,

- Normalize edilmiş ikili karşılaştırmalar matrisinin her bir satırındaki elemanların 
Tablo 3. Arazi kalite indeksi için seçilen parametreler ve etkinlikleri

\begin{tabular}{|c|c|c|c|}
\hline & Parametreler & Etkinliği & Kaynak \\
\hline \multirow{4}{*}{$\begin{array}{l}\text { Arazi } \\
\text { indikatörleri }\end{array}$} & Derinlik & $\begin{array}{l}\text { Kök gelişimi, su depolama } \\
\text { kapasitesi }\end{array}$ & Sarkar ve ark. (2014) \\
\hline & Eğim & Yüzey akışı ile kayıplar & Anonymous (1976) \\
\hline & Taşlık & $\begin{array}{l}\text { Bitki çıkışları, toprak } \\
\text { işleme, su tutulumu }\end{array}$ & Miller ve ark. (1984), Sauer ve ark. (2010) \\
\hline & Drenaj & $\begin{array}{l}\text { Tuzluluk, kök gelişimi, } \\
\text { besin elementleri kayb1 }\end{array}$ & Siegel ve ark. (1980) \\
\hline \multirow{3}{*}{$\begin{array}{l}\text { Fiziksel } \\
\text { indikatörler }\end{array}$} & Tekstür & $\begin{array}{l}\text { İnfiltrasyon hızı, strüktür } \\
\text { tipi, bitki-su ilişkileri }\end{array}$ & Ashraf ve ark. (2010), Ahmed ve ark. (2016) \\
\hline & $\begin{array}{l}\text { Hacim } \\
\text { ağırlığ } 1\end{array}$ & $\begin{array}{l}\text { Toprak sıkışması, } \\
\text { havalanma, infilttrasyon }\end{array}$ & Şeker ve Iş̧1dar (2000), Pagliai ve ark. (2004) \\
\hline & Faydalı su & $\begin{array}{l}\text { Rezerv su miktarı, bitki su } \\
\text { tüketimi, kuraklığa direnç }\end{array}$ & Letey (1958) \\
\hline \multirow{6}{*}{$\begin{array}{l}\text { Kimyasal } \\
\text { indikatörler }\end{array}$} & $\mathrm{EC}$ & $\begin{array}{l}\text { Ozmotik potansiyel, iyon } \\
\text { toksisitesi }\end{array}$ & Miransari ve Smith (2007) \\
\hline & $\mathrm{pH}$ & $\begin{array}{l}\text { Besin yarayışlılı̆̆ } \\
\text { mikrobiyal aktivite }\end{array}$ & Baridón ve ark. (2014) \\
\hline & $\begin{array}{l}\text { Organik } \\
\text { madde }\end{array}$ & $\begin{array}{l}\text { Toprak kalitesi, biyolojik } \\
\text { aktivite }\end{array}$ & $\begin{array}{l}\text { Kurzatkowski (2004), Riley ve ark. (2008), Guo } \\
\text { ve ark. (2015) }\end{array}$ \\
\hline & $\mathrm{N}$ & \multirow{3}{*}{$\begin{array}{l}\text { Vejetatif gelişim, besin } \\
\text { elementi dengesi, bitki } \\
\text { metabolizmasi, verim }\end{array}$} & \multirow{3}{*}{$\begin{array}{l}\text { Lindsay ve Norvell (1978), Anonymous, (1990), } \\
\text { Marschner ve ark. (1996), Gezgin ve Hamurcu } \\
\text { (2006), Jiang ve ark. (2006), Laghari ve ark. } \\
\text { (2010) }\end{array}$} \\
\hline & $\mathrm{P}$ & & \\
\hline & K & & \\
\hline
\end{tabular}

Tablo 4. Arazi kalite indeksinde kullanılacak parametrelerin uzman görüşü ve literatür bilgisi kullanılarak belirlenmiş alt skor değerleri

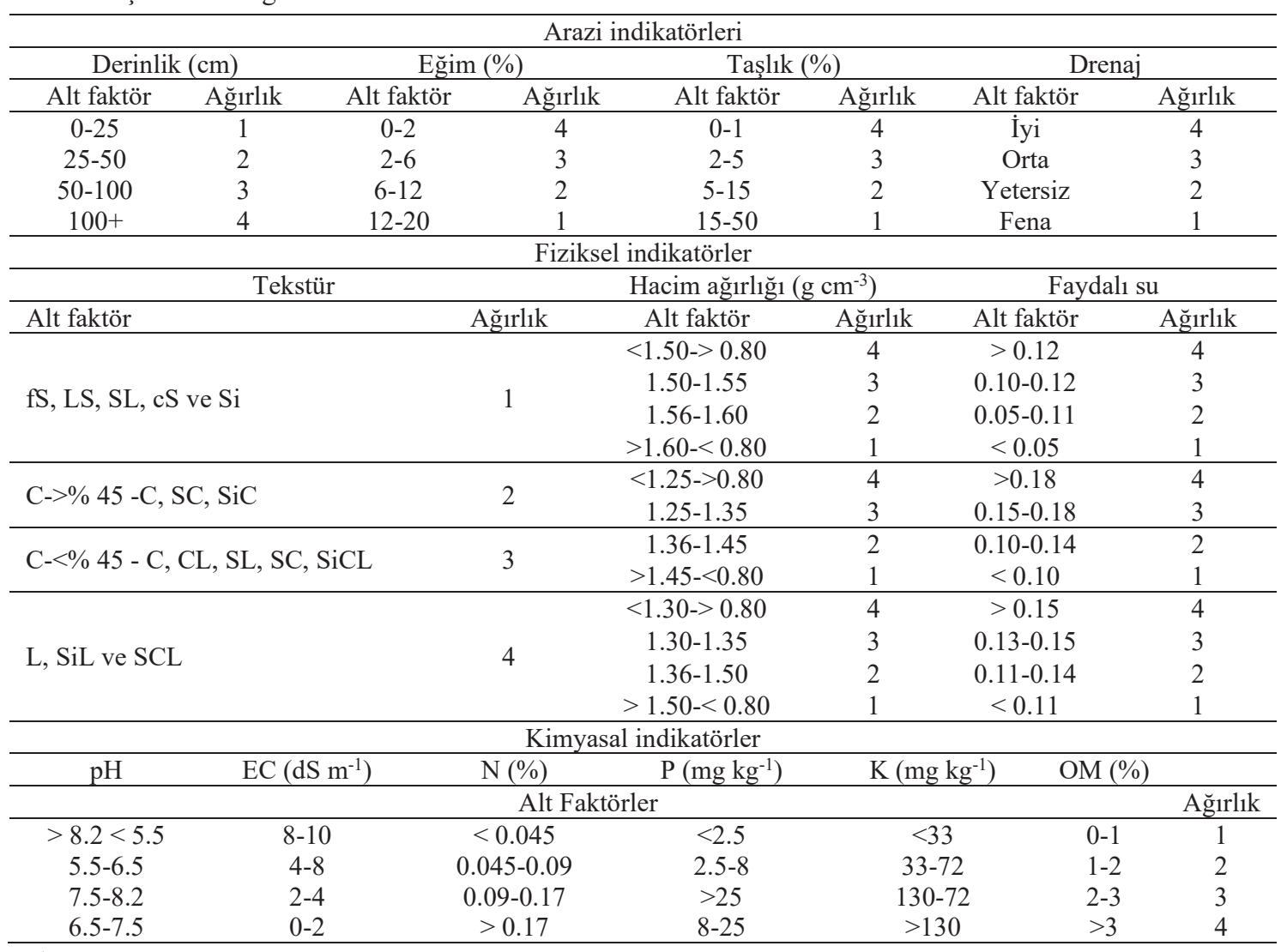

fS: İnce kum, LS: Tınlı kum, SL: Kumlu tın, S: Kum, C: Kil, Si: Silt, SiC: Siltli kil, cS: Kaba kum, SC: Kumlu kil, CL: Killi tın, SiCL: Siltli killi tın, L: Tın, SiL: Siltli tın, SCL: Kumlu killi tın, OM: Organik madde 
aritmetik ortalaması alınarak her bir parametre için Öncelik Vektörlerinin Hesaplanmas1,

- İkili karşılaştırmalar matrisindeki her bir parametrenin bulunduğu sütunun toplam değeri ile o parametrenin öncelik vektörü çarpılarak elde edilen yeni vektörlerin toplanması sonucu En Yüksek Öncelik Vektörünün $\left(\lambda_{\max }\right)$ elde edilmesi,

- $\lambda$ max ve parametre sayısı (çalışma için $\mathrm{n}=13)$ Eşitlik 1'de verilen modelde kullanılarak Tutarlılık İndeksinin hesaplanmas1,

$T \dot{\mathrm{I}}=\frac{\lambda \max -n}{n-1}$

- Tutarlılık İndeks değerinin Saaty (2008)'e göre belirtilen 13 parametre için Rastgelelilik İndeks değerine $(n=13$ ise; $\mathrm{R} \dot{I}=$ 1.56) bölünmesi sonucu Tutarlılık Oranın belirlenmesi işlem adımları gerçekleştirilmiştir.

İkili karşılaştırmalar sonucu belirlenen ağırlıkların Tutarlılık Oranı $<0.10$ olduğu durumlarda yöntemin geçerli olduğun bildirilmiştir (Saaty, 2008).

\subsubsection{Haritalama birimlerinin arazi kalite indeks değerlerinin hesaplanması}

Çalışma alanı arazilerinin kalite skorlarının belirlenebilmesi amacıyla parametrik bir yaklaşım olan Doğrusal Kombinasyon Tekniği (DKT), CBS programı olan ArcGIS 9.3 ile vektörel olarak hazırlanan 43 farklı haritalama birimine uygulanmıştır. Doğrusal Kombinasyon Tekniği, seçilen parametreler için belirlenen alt faktör puanlarının ve ağırlık oranlarının birlikte değerlendirilmesinde benzer birçok çalışmada kullanılan pratik ve güvenilir bir matematiksel eşitliktir (Eastman ve Jiang, 1996; Dengiz ve Sarığlu, 2013; Romano ve ark., 2015). Doğrusal Kombinasyon Tekniği yaklaşımına ilişkin model Eşitlik 2'de verilmiştir.

$$
A K \dot{\mathrm{I}}=\sum_{i=1}^{n}(W i \cdot X i)
$$

Burada AKİ, arazi kalite indeksini; $\mathrm{W}_{\mathrm{i}}$, i parametresinin ağırlık değerini; $X_{i}$, i parametresine ait alt kriter puanını; n, ele alınan parametrelerin toplam sayısını ifade etmektedir.

Doğrusal Kombinasyon Tekniği ile hesaplanan AKİ sınıf aralıkları Jenks (1967)'ye göre, ArcGIS 9.3 yazılımı kullanılarak belirlenmiştir (Tablo 5). Tüm haritalama birimleri için hesaplanan indeks değerlerinin histogram grafiğinden doğal kırınımın aralıklarına göre kategorizasyonu yapılmıştır (Zhang ve ark., 2015). Bu sayede bölgeye özgü parametrelerin son skor değerine etki derecelerine göre indis geliştirilmiştir.

Tablo 5. Tarımsal amaçlı arazi kalite sınıfları

\begin{tabular}{lcc}
\hline Nitelik & Sınıf & İndeks değeri \\
\hline Yüksek & I & $>3.443$ \\
Orta & II & $3.186-3.443$ \\
Düşük & III & $2.949-3.185$ \\
Çok düşük & IV & $<2.949$ \\
\hline
\end{tabular}

Arazi kalite sinıfları, tarımsal bitki yetiştiriciliğine ve gelişimine kısıtlayıcı faktör bulunmadığı durumlarda "Yüksek: I", bazı hafif etkili kısıtlayıcı faktörlerin bulunduğu durumlarda "Orta: II", ciddi seviyede kültivasyonu etkileyen faktörlerin bulunduğu durumlarda "Düşük: III" ve bitkisel yetiştiricilik için elverişli olmayan koşullarda "Çok Düşük: IV" olarak kategorize edilmiştir.

\section{Bulgular ve Tartışma}

Çalışma alanı topraklarının laboratuvar analiz sonuçları ve tanımlayıcı istatistikleri Tablo 6'da sunulmuştur. Bölge toprakları kil ve kum bünye sınıflarında geniş bir dağılım göstermekte olup bazı bölgelerde kil içeriği \% 60’a, kum içeriği \% 78'e ulaşmaktadır. Topraklarının hacim ağırlığı değerleri ince bünyeli alanlarda $1.21-1.28 \mathrm{~g} \mathrm{~cm}^{-3}$ arasinda değişim gösterirken, tanecik büyüklük çapı ve oranı artıkça $1.58 \mathrm{~g} \mathrm{~cm}^{-3}$ değerine çıkmaktadır. Hacim

Tablo 6. Toprak serilerinin fiziksel ve kimyasal özelliklerine ait tanıtıcı istatistikler

\begin{tabular}{|c|c|c|c|c|c|c|c|}
\hline İndikatör & $\mathrm{n}$ & Minimum & Maksimum & Ortalama & $\mathrm{StSp}$ & SE Ortalama & Varyans \\
\hline $\mathrm{HA}, \mathrm{gr} \mathrm{cm}^{-3}$ & 13 & 1.250 & 1.580 & 1.343 & 0.120 & 0.049 & 0.015 \\
\hline $\mathrm{FS}, \%$ & 31 & 6.60 & 15.10 & 12.70 & 3.40 & 1.39 & 11.54 \\
\hline Kum, \% & 31 & 6.30 & 78.50 & 31.1 & 24.50 & 10.0 & 600.30 \\
\hline Silt, \% & 31 & 10.70 & 44.70 & 36.08 & 12.67 & 5.17 & 160.48 \\
\hline Kil, \% & 31 & 10.80 & 66.20 & 35.73 & 17.71 & 7.23 & 313.49 \\
\hline OM, $\%$ & 31 & 0.700 & 3.100 & 1.810 & 0.826 & 0.337 & 0.683 \\
\hline $\mathrm{pH}, 1: 2.5$ & 31 & 7.40 & 8.12 & 7.82 & 0.24 & 0.098 & 0.05 \\
\hline $\mathrm{EC}, \mathrm{dS} \mathrm{m}^{-1}$ & 31 & 0.350 & 0.935 & 0.707 & 200.1 & 81.7 & 40034.2 \\
\hline $\mathrm{P}, \mathrm{mg} \mathrm{kg}^{-1}$ & 31 & 4.00 & 13.00 & 9.50 & 3.51 & 1.43 & 12.30 \\
\hline $\mathrm{N}, \%$ & 31 & 0.03 & 0.15 & 0.0850 & 0.0414 & 0.0169 & 0.0017 \\
\hline $\mathrm{K}, \mathrm{mg} \mathrm{kg}^{-1}$ & 31 & 110.0 & 560.0 & 309.2 & 185.3 & 75.7 & 34354.6 \\
\hline
\end{tabular}

n: Örnekleme büyüklüğ̈̈, HA: Hacim ağırlığı, FS: Faydalı su kapasitesi, OM: Organik madde, StSp: Standart sapma 
ağırlığının tersi durum faydalı su içeriği değerlerinde gözlemlenmiş ve kum içeriği arttıkça faydalı su değerinin azaldığı belirlenmiştir. İşletme alanı topraklarında tuzluluk problemi belirlenmemiştir, ancak pH, 7.40-8.12 değerleri arasında hafif alkalin sınırında değişim göstermektedir. Bölge topraklarının N ve yarayışlı $\mathrm{P}$ içerikleri düşük, yarayışlı $\mathrm{K}$ kapsamı yeter seviyededir. Tarımsal amaçlı arazi kalitesinin önemli göstergelerinden olan organik madde içeriği bölge toprakları için az-orta seviyede değişmekte olup, derinliğe bağlı olarak alt horizonlarda azalmaktadır. Ayrıca çalışma alanı az (\% 2-5) ve orta derecede (\% 5-15), 6-20 cm çaplı taşlık problemi ve yetersiz drenaj koşulları olan, farklı derinlik sınıflarında ve fizyografik üniteleri alüvyal depozitlerden oluşan değişik eğim gruplarındaki toprak fazlarından oluşmaktadır (Tablo 6). Çalışma alanın toprak özellikleri bölgede farklı kalite sınıflarını temsil edecek nitelikte tarım arazileri varlığının da bir göstergesidir.

Toprak serilerine ait 43 haritalama biriminin tarımsal açıdan arazi kalitelerinin belirlenmesine yönelik olarak arazi çalışmaları ve laboratuvar analiz bulgularına göre seçilen indikatörler için yapılan ikili karşılaştırmalara dayalı ağırlık değerleri Tablo 7'de verilmiştir. Oluşturulan ikili karşılaştırma matrisi vasıtasıyla parametrelerin birbirlerine göre önceliği Saaty (2008)'e göre tanımlanmış ve 0.33-5.00 arası değişen ağırlık değerleri hesaplanmıştır. İkili karşılaştırmalar matrisindeki her bir parametrenin bulunduğu sütunun toplam değeri ile o parametrenin öncelik vektörü çarpılarak elde edilen yeni vektörlerin toplanması sonucu En Yüksek Öncelik Vektörü; $\lambda_{\max }=104.792$ olarak belirlenmiştir. En yüksek öncelik vektörü $\left(\lambda_{\max }\right)$ ve parametre sayısı $(n=13)$ kullanılarak, Tutarlılık İndeksi; Tİ= 0.149 değeri elde edilmiştir. Tutarlılık indeks değerinin Saaty (2008)'e göre belirtilen 13 parametre için Rastgelelilik İndeks değerine ( $\mathrm{n}=13$ ise; $\mathrm{R} \dot{\mathrm{I}}=1.56)$ bölünmesi sonucu Tutarlılık Oran1; TO=0.096, olarak bulunmuştur. Tutarlılık oranının $<0.10$ olması parametrelerin ikili karşılaştırması sonucu belirlenen öncelik vektörlerinin (ağırlık değerleri) uygun olduğunu ve yöntemin geçerli olduğunun bulgusudur. $\mathrm{Bu}$ sonuca esas teşkil eden unsur, çalışmada AHS metodu kullanılarak değerlendirmeye alınan indikatörlerin ikili karşılaştırmasında; (1) bitkisel yetiştiricilik için arazi koşulları, (2) indikatör ve parametrelerin birbirlerine göre önemi, (3) parametrelerin kültüvasyonu kısıtlayıcı etkilerinin giderilebilirliği ve (4) parametrelerin bölge topraklarında ki değişim derecelerinin dikkate alınarak ağırlıklandırmalarının yapılmasıdır. Nitekim bölgesel ölçekte yürütülen çalışmalarda bölgeye özgün karakteristik özelliklerin (pH gibi) ve kısitlayıcı etkisi kolay giderilebilir besin elementi kapsamlarının ağırlık değerinin diğer parametrelere nazaran düşük olması, ancak arazide iyileştirilmesi veya değiştirilmesi ekonomik olmayan (örneğin eğim derecesi, etkili toprak derinliği) ve sürekli risk arz eden (drenaj, taşlılık, erozyon) özelliklerin daha yüksek oranda ağırlıklandırılması önerilmektedir (Patrono, 1998; Dengiz ve Sarığlu, 2013; Ahmed ve ark., 2016). Bununla birlikte ortamda ki varlığ bitkisel üretim için mutlak gerekli olmayan ancak bulunması durumunda toprak kalitesi üzerine etkinliği faydalı olan (örneğin organik madde) parametrelerin de orta düzey de ağırlık oranına sahip olması gerektiği bilinmektedir (Riley ve ark., 2008).

Tüm bu değerlendirmeler 1şı̆̆ında bölge ekolojisi dikkate alarak yapılan ikili karşılaştırmalar sonucu işletme arazilerinin tarımsal açıdan kalitesinin ölçülmesinde ele alınan indikatörlerin etki dereceleri yüksek, orta ve düşük olarak 3 grup ta değerlendirilmiştir. AHS uygulaması sonucu derinlik (\% 12.5), eğim (\% 12), EC (\% 11.1) ve bünye (\% 10.7) indikatörlerinin yüksek oranda ağırlık katsayılarına sahip olduğu belirlenmiştir. Nitekim işlemeli tarım açısından ve özellikle eğim ve bünye gibi özelliklerin kalıtımsal ve durağan özelliklerinden dolayı değiştirilememesi, EC'nin ise bitkisel üretimde sınırlandırıcı hassas parametre olması arazilerin değerlendirilmesinde bu indikatörlerin etki dereceleri yüksek katsayılar almasına neden olmuştur (Dengiz ve ark., 2014). Diğer taraftan taşlık (\% 9.5), drenaj (\% 9.0), faydalı su kapasitesi (\% 7.6), hacim ağırlığı (\% 6.6) ve organik madde miktarı (\% 6.0) orta seviye ağırlık değeri almıştır. $\mathrm{Bu}$ durum sslah edilebilir arazi koşullarının ve organik madde arttırıcı uygulamalar ile iyileştirilebilir fiziksel özelliklerin AKİ sınıfını olumlu yönde değiştirebilir olmasının da bir bulgusudur. Çünkü bu indikatörler toprakların dinamik özellikleri içerisinde yer almaları nedeniyle, antropojenik etkiler ile değişikliğe uğratılabilmektedir (Dengiz, 2019). Nitekim tarım arazilerinde taşlık ve drenaj koşullarının 1slah edilmesi ile mekanizasyonun kolaylaştığı, bitki çıkışlarının ve verim değerlerinin $\operatorname{arttı̆̆}$ belirtilmiştir (Miller ve Guthrie, 1984; Sauer ve ark., 2010). Bunlara ek olarak organik maddenin su tutulumu, toprak sıkışması, havalanma ve biyolojik aktivite üzerine olumlu etkileri hacim ağırlığı ve faydalı su kapasitesinin kisitlayıc1 etkisini azaltmakta ve toprak kalitesini arttırmaktadır (Guo ve ark., 2015; Kurzatkowski, 2004). Aynı zamanda bölge arazilerinin deniz seviyesinden yüksekliği (1-7 m), taban suyu seviyesi (1.5-2 m), yillık ortalama yağış miktarı ( $1200 \mathrm{~mm})$ ve işletme çevresinde ve içiresinde yıl içerisinde farklı debi ve 
Tablo 7. İndikatörlere ait ağırlık değerlerinin belirlenmesine yönelik AHS tekniği hesaplamaları

\begin{tabular}{|c|c|c|c|c|c|c|c|c|c|c|c|c|c|}
\hline \multicolumn{14}{|c|}{ İkili karşı1aştırma matrisi } \\
\hline İndikatörler & Derinlik & Eğim & EC & Taşlik & Bünye & $\mathrm{OM}$ & $\mathrm{pH}$ & Drenaj & HA & $\mathrm{N}$ & $\mathrm{P}$ & K & FS \\
\hline Derinlik & 1.00 & 1.00 & 3.00 & 1.00 & 1.00 & 3.00 & 3.00 & 1.00 & 3.00 & 3.00 & 3.00 & 3.00 & 2.00 \\
\hline Eğim & 1.00 & 1.00 & 1.00 & 1.00 & 1.00 & 3.00 & 3.00 & 3.00 & 3.00 & 3.00 & 3.00 & 3.00 & 2.00 \\
\hline $\mathrm{EC}$ & 0.33 & 1.00 & 1.00 & 3.00 & 1.00 & 3.00 & 1.00 & 2.00 & 3.00 & 2.00 & 2.00 & 2.00 & 3.00 \\
\hline Taşlık & 1.00 & 1.00 & 0.33 & 1.00 & 1.00 & 3.00 & 1.00 & 0.33 & 2.00 & 3.00 & 3.00 & 3.00 & 3.00 \\
\hline Bünye & 1.00 & 1.00 & 1.00 & 1.00 & 1.00 & 3.00 & 3.00 & 3.00 & 1.00 & 3.00 & 3.00 & 3.00 & 1.00 \\
\hline $\mathrm{OM}$ & 0.33 & 0.33 & 0.33 & 0.33 & 0.33 & 1.00 & 3.00 & 1.00 & 1.00 & 3.00 & 3.00 & 3.00 & 0.33 \\
\hline $\mathrm{pH}$ & 0.33 & 0.33 & 1.00 & 1.00 & 0.33 & 0.33 & 1.00 & 2.00 & 0.33 & 2.00 & 2.00 & 2.00 & 0.33 \\
\hline Drenaj & 1.00 & 0.33 & 0.50 & 3.00 & 0.33 & 1.00 & 0.50 & 1.00 & 3.00 & 3.00 & 3.00 & 3.00 & 2.00 \\
\hline HA & 0.33 & 0.33 & 0.33 & 0.50 & 1.00 & 1.00 & 3.00 & 0.33 & 1.00 & 3.00 & 3.00 & 3.00 & 1.00 \\
\hline $\mathrm{N}$ & 0.33 & 0.33 & 0.50 & 0.33 & 0.33 & 0.33 & 0.50 & 0.33 & 0.33 & 1.00 & 3.00 & 3.00 & 0.33 \\
\hline $\mathrm{P}$ & 0.33 & 0.33 & 0.50 & 0.33 & 0.33 & 0.33 & 0.50 & 0.33 & 0.33 & 0.33 & 1.00 & 1.00 & 0.33 \\
\hline K & 0.33 & 0.33 & 0.50 & 0.33 & 0.33 & 0.33 & 0.50 & 0.33 & 0.33 & 0.33 & 1.00 & 1.00 & 0.33 \\
\hline FS & 0.50 & 0.50 & 0.33 & 0.33 & 1.00 & 3.00 & 3.00 & 0.50 & 1.00 & 3.00 & 3.00 & 3.00 & 1.00 \\
\hline Toplam & 7.83 & 7.83 & 10.33 & 13.17 & 9.00 & 22.33 & 23.00 & 15.17 & 19.33 & 29.67 & 33.00 & 33.00 & 16.67 \\
\hline \multicolumn{14}{|c|}{ Normalize edilmiş ikili karşılaştırmalar matrisi } \\
\hline İndikatörler & Derinlik & Eğim & EC & Taşlık & Bünye & $\mathrm{OM}$ & $\mathrm{pH}$ & Drenaj & HA & $\mathrm{N}$ & $\mathrm{P}$ & K & FS \\
\hline Derinlik & 0.128 & 0.128 & 0.290 & 0.076 & 0.111 & 0.134 & 0.130 & 0.066 & 0.155 & 0.101 & 0.091 & 0.091 & 0.120 \\
\hline Eğim & 0.128 & 0.128 & 0.097 & 0.076 & 0.111 & 0.134 & 0.130 & 0.198 & 0.155 & 0.101 & 0.091 & 0.091 & 0.120 \\
\hline EC & 0.043 & 0.128 & 0.097 & 0.228 & 0.111 & 0.134 & 0.043 & 0.132 & 0.155 & 0.067 & 0.061 & 0.061 & 0.180 \\
\hline Taşlık & 0.128 & 0.128 & 0.032 & 0.076 & 0.111 & 0.134 & 0.043 & 0.022 & 0.103 & 0.101 & 0.091 & 0.091 & 0.180 \\
\hline Bünye & 0.128 & 0.128 & 0.097 & 0.076 & 0.111 & 0.134 & 0.130 & 0.198 & 0.052 & 0.101 & 0.091 & 0.091 & 0.060 \\
\hline $\mathrm{OM}$ & 0.043 & 0.043 & 0.032 & 0.025 & 0.037 & 0.045 & 0.130 & 0.066 & 0.052 & 0.101 & 0.091 & 0.091 & 0.020 \\
\hline $\mathrm{pH}$ & 0.043 & 0.043 & 0.097 & 0.076 & 0.037 & 0.015 & 0.043 & 0.132 & 0.017 & 0.067 & 0.061 & 0.061 & 0.020 \\
\hline Drenaj & 0.128 & 0.043 & 0.048 & 0.228 & 0.037 & 0.045 & 0.022 & 0.066 & 0.155 & 0.101 & 0.091 & 0.091 & 0.120 \\
\hline HA & 0.043 & 0.043 & 0.032 & 0.038 & 0.111 & 0.045 & 0.130 & 0.022 & 0.052 & 0.101 & 0.091 & 0.091 & 0.060 \\
\hline $\mathrm{N}$ & 0.043 & 0.043 & 0.048 & 0.025 & 0.037 & 0.015 & 0.022 & 0.022 & 0.017 & 0.034 & 0.091 & 0.091 & 0.020 \\
\hline P & 0.043 & 0.043 & 0.048 & 0.025 & 0.037 & 0.015 & 0.022 & 0.022 & 0.017 & 0.011 & 0.030 & 0.030 & 0.020 \\
\hline K & 0.043 & 0.043 & 0.048 & 0.025 & 0.037 & 0.015 & 0.022 & 0.022 & 0.017 & 0.011 & 0.030 & 0.030 & 0.020 \\
\hline FS & 0.064 & 0.064 & 0.032 & 0.025 & 0.111 & 0.134 & 0.130 & 0.033 & 0.052 & 0.101 & 0.091 & 0.091 & 0.060 \\
\hline \multicolumn{14}{|c|}{ Öncelik vektör } \\
\hline İndikatörler & \multicolumn{5}{|c|}{$\begin{array}{l}\text { Normalize edilmiş } \\
\text { satırlar toplamı }\end{array}$} & \multicolumn{6}{|c|}{$\begin{array}{l}\text { Normalize edilmiş } \\
\text { satırlar ortalamas1 }\end{array}$} & \multicolumn{2}{|c|}{$\begin{array}{l}\text { Öncelik } \\
\text { vektörü }\end{array}$} \\
\hline Derinlik & \multicolumn{5}{|c|}{1.622} & \multicolumn{6}{|c|}{$1.622 / 13$} & \multicolumn{2}{|c|}{0.125} \\
\hline Eğim & \multicolumn{5}{|c|}{1.560} & \multicolumn{6}{|c|}{$1.560 / 13$} & \multicolumn{2}{|c|}{0.120} \\
\hline $\mathrm{EC}$ & \multicolumn{5}{|c|}{1.439} & \multicolumn{6}{|c|}{$1.439 / 13$} & \multicolumn{2}{|c|}{0.111} \\
\hline Taşlık & \multicolumn{5}{|c|}{1.241} & \multicolumn{6}{|c|}{$1.241 / 13$} & \multicolumn{2}{|c|}{0.095} \\
\hline Bünye & \multicolumn{5}{|c|}{1.396} & & & 1.39 & $96 / 13$ & & & & 107 \\
\hline $\mathrm{OM}$ & & & 0.776 & & & & & 0.77 & $76 / 13$ & & & 0.0 & 060 \\
\hline $\mathrm{pH}$ & & & 0.711 & & & & & 0.71 & $11 / 13$ & & & 0.0 & 055 \\
\hline Drenaj & & & 1.174 & & & & & 1.17 & $74 / 13$ & & & 0.0 & 090 \\
\hline HA & & & 0.858 & & & & & 0.85 & $58 / 13$ & & & 0.0 & 066 \\
\hline $\mathrm{N}$ & & & 0.507 & & & & & 0.50 & 7/13 & & & 0.0 & 039 \\
\hline $\mathrm{P}$ & & & 0.364 & & & & & 0.36 & 64/13 & & & 0.0 & 028 \\
\hline K & & & 0.364 & & & & & 0.36 & $64 / 13$ & & & 0.0 & 028 \\
\hline FS & & & 0.989 & & & & & 0.98 & 39/13 & & & & 076 \\
\hline
\end{tabular}

kotlarda akan dereler dikkate alındığında erozyon riski ve tuzluluk probleminin daima bir potansiyelinin olduğu, bu durumun indikatörlerin ağırlık değerlerine de yansıdığı belirlenmiştir.

AHS uygulaması ile $\mathrm{pH}(\%$ 5.5) ve N (\% 3.9), P (\% 2.8), K (\% 2.8) içerikleri düşük ağırlık puanları ile fonksiyon kurmuştur. Toprağın elverişsli NPK içeriğine bağlı olarak bitkide büyüme, verim ve besin alım özelliklerinin önemli ölçüde arttığı ve gübrelemeye bağlı ekonomik girdilerin azaldığ1 bilinmektedir (Jiang ve ark., 2006; Dengiz, 2019).
Ancak besin elementi kapsamları farklı zamanlarda yapılan gübre uygulamaları ile arttırılabilmektedir. $\mathrm{Bu}$ nedenle NPK kapsamının düşük ağırlık değerinde oranlanması iyileştirilmesi kolay bir faktör olmasındandır. Burada dikkat çekici husus hemen tüm arazi kalite indislerine konu olan $\mathrm{pH}$ indikatörünün ağırlık katsayıdır. Nitekim $\mathrm{pH}$ doğrudan ya da dolaylı olarak toprak içerisinde meydana gelen birçok fiziksel, kimyasal ve biyolojik olayı etkilemekte (Baridón ve Casas, 2014), yüksek pH değerlerinde fosfor ve iz 
elementlerin toprakta hareket kabiliyetinin azaldı $\breve{g} 1$, asit reaksiyonlu topraklarda toksik elementlerin bitki tarafından alınabilirliğinin arttığı ifade edilmiştir (Leonard ve ark., 1976). Ancak araştırmada pH'nın düşük ağırlık katsayısı ile değerlendirilmesi bölgesel ölçekte çalışmanın yürütülüyor olması ve bölge arazilerinin $\mathrm{pH}$ değerlerinin çarpıcı bir değişim göstermemesinden ileri gelmektedir. Çalışmada AKİ ile belirlenen her bir haritalama birimine ait tarımsal arazi kalite haritası Şekil 2'de, alansal büyüklükleri Tablo 8'de sunulmuştur.

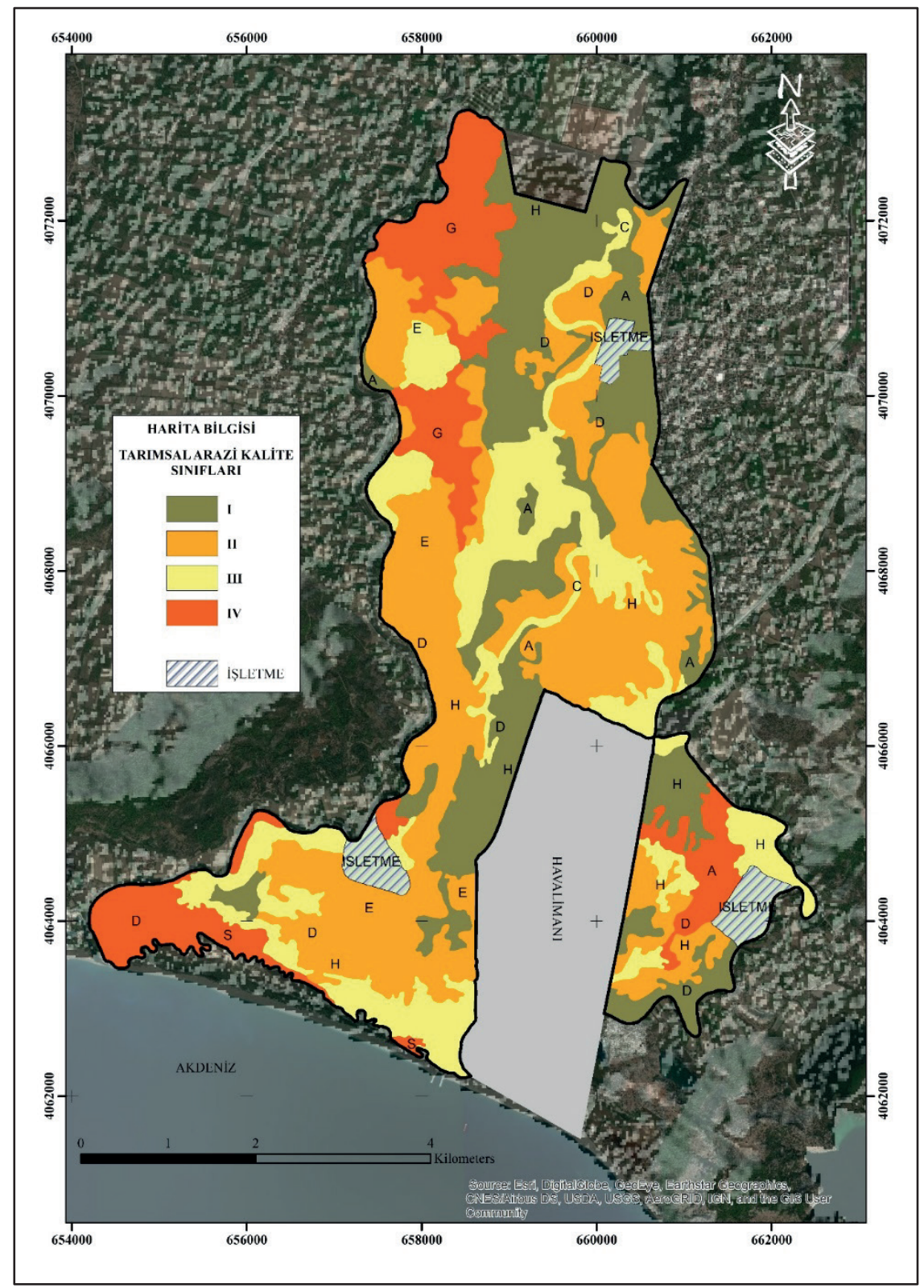

Şekil 2. AKİ indeksine göre tarımsal arazi kalitesi haritası

AKİ değerlendirmesi sonucu çalışma alanında sığ toprak derinliği, çok dik eğim ve $50 \mathrm{~cm}$ 'den az derinlikte anakaya varlığı nedeni ile Gökdağ serisi arazilerinin tamamı, tarım işletmesinin güneybatısında kıyı kumulları ile sınırı bulunan, düşük organik madde içerikli, kumlu tın tekstürlü, sı ğ derinlik, yetersiz drenaj koşulları ve taşlık ihtiva eden Söğüt sersisi ve Dalaman serisinin bazı fazları
Tablo 8. AKİ sonucu belirlenen sınıf büyüklükleri [106 ha (\% 3.16) işletme alanı hariç]

\begin{tabular}{lccc}
\hline Nitelik & Sinıf & $\begin{array}{c}\text { Alan } \\
\text { (ha) }\end{array}$ & $\begin{array}{c}\text { Dağ } 1 \text { lım } \\
(\%)\end{array}$ \\
\hline Yüksek & I & 873.61 & 25.09 \\
Orta & II & 1217.44 & 36.47 \\
Düşük & III & 654.99 & 19.62 \\
Çok düşük & IV & 522.68 & 15.66 \\
\hline
\end{tabular}


ile Adaköy serisinin sığ toprak derinlikli ve yetersiz drenaj koşullarındaki güneydoğu fazı çok düşük tarımsal arazi kalite nitelikli olarak belirlenmiştir. Bölge arazilerinde $50 \mathrm{~cm}$ 'den fazla toprak derinliğine sahip ancak ağır bünyeli (kil>\% 45), y1l içerisinde mevsimsel olarak taban suyu seviyesinin yükseldiği ve taşkın riski barındıran Eskiköy ve Havaalanı serilerinin güneydoğu-güneybatı fazları ve Camikırı serisi arazileri düşük nitelikli tarımsal arazi kalitesine sahip olarak sınıflandırılmıştır.

İşletmede I. ve II. sınıf nitelikli araziler de toprak derinliği, tekstür, drenaj koşulları ve faydalı su kapasitesinin değişen oranlarının sınıf dağılımlarını etkilediği belirlenmiştir. Çalışma ile bölge arazilerinin kalite son indeks değerlerine hacim ağırlığı, $\mathrm{pH}$, organik madde ve NPK indikatörlerinin etkisinin anlamlı farklılıklar oluşturmadığı, bu durumun indikatörlerin birbirine yakın değerlere sahip olmasından ileri geldiği belirlenmiştir.

Çalışma ile elde edilen bir diğer bulgu Anonim (1982)'e göre bölge arazilerinin tamaminda belirlenen değişen seviyelerde tuzluluk probleminin günümüzde ortadan kalkmış olmasıdır. Bu durum gerekli iyileştirme önlemlerinin alınması durumunda (drenaj kanallarının geliştirilmesi ve yeni kanallar açılması, derin sürüm ve patlatma, organik madde ilavesi, taş toplama) düşük kalitedeki bölge arazilerinin orta hatta yüksek kalite niteliğinde sınıflanabileceğinin bir göstergesidir.

\section{Sonuçlar}

$\mathrm{Bu}$ çalışma ile Dalaman Tarım İşletme Müdürlüğü'ne ait 3338.61 hektar tarım arazisinde bölgesel ölçekte ilgili toprak ve arazi göstergeleri dikkate alınarak tarımsal amaçlı arazi kalite indeksi geliştirilmiş ve araziler sınıflandırılmıştır. Çalışmada AKI'nin geliştirilmesinde kullanılacak parametrelerin tek başına ve birbirleri ile etkileşimlerinin değerlendirmesinde, vejetasyon isteklerine göre önem seviyelerinin belirlenmesinde, belli bir coğrafyada mekânsal dağılımlarının anlamlandırılmasında ve çiftçi uygulamalarının yorumlanmasında literatür bilgisini, CBS analiz tekniklerini ve geçmiş deneyimlerini kullanan toprak etüt ve haritalama uygulamalarında uzman bilim insanlarının görüşünün Analitik Hiyerarşik Süreç Modeli ile kullanımı başarılı bulunmuş ve tutarlı sonuçlar elde edilmiştir. Bulguların CBS ortamına entegrasyonu ve analizi ile karmaşık ve çok faktörlü bir yapı olan arazi kavramının kantitatif olarak değerlendirilmesi yapılmış ve kartografik temelli yazılımların benzer çalışmalarda kullanımı önerilmiştir.

Bölge arazilerinin tarımsal amaçlı kalite değerlendirmesinde en yüksek etkiyi fizyoğrafik indikatörler ile toprak tekstür dağılımı ve EC parametresi göstermiştir. $\mathrm{Bu}$ nedenle yönetimsel planlamalarda, tesviye çalışmalarında ve alternatif kullanımların seçiminde ilgili indikatörlerin öncelikle dikkate alınması gerekmektedir. Toprak fiziksel özellikleri olan hacim ağırlığ kapasitesi değerlerindeki değişimler tarımsal yetiştiricilik açısından toprak sıkışması, sürüm zamanı, çimlenme-çıkış ve bitki su tüketimi parametrelerini doğrudan ilgilendiren indikatörlerdir. Bu nedenle geliştirilen AKİ için orta seviyede ağırlık katsayıları ile fonksiyonlanmaları uygun bulunmuştur. Nitekim her iki indikatör de toprak tekstürü ile yüksek düzeyde koreledir ve farklı tekstürlerde uygun değer aralıkları değişmektedir. $\mathrm{Bu}$ durum tekstür sınıfının hacim ağırlığı ve faydalı su kapasitesinden daha yüksek oranda ağırlıklandırılması ile açıklanmaktadır. Benzer şekilde drenaj ve taşlılık problemleri orta seviye ağırlık katsayısına sahiptir ve ıslah edilmesi durumunda arazi kalitesini arttırıc1, tedbir alınmaması durumunda azaltıcı etkileri AKİ modelinde yansitılmıştır.

Kimyasal indikatörlerden $\mathrm{pH}$ ve besin elementi kapsamlarının düşük ağırlık katsayıları göstermesi birbirleri üzerine etkileri bakımından uygundur. Ancak bölge toprakları daimî bir tuzluluk riski taşımaktadır. Bu nedenle besin elementi kapsamları ve alt horizonlarda gelişebilecek $\mathrm{pH}$ artışının (sodikleşme başlangıcı), EC değerleri ile dikkatle takip edilmesi, gübreleme programlarının ilgili belirteçler referans alınarak hazırlanması önerilmiştir.

Çalışma sonucu elde edilen bulgular, arazi gözlemleri, geçmiş çalışmalar ve uzman görüşü doğrultusunda bölge ekolojisini ve pedogenesisini temsil eden, benzer coğrafyaların ve iklim tiplerinin alüviyal ovalarında kullanılabilir bir tarımsal arazi kalite indisi geliştirilmiş, çıktıları tartışılmış ve başarısı sebep-sonuç ilişkileri ile ortaya konulmuştur. Ancak AKİ modelinin genel-geçer bir indis olarak kullanılabilir olması için benzer iklim koşullarında, farklı toprak tiplerinde ve değişim derecesi yüksek indikatörlerin seçimi ile denenmesi onu geliştirecektir. Bu sayede özellikle $\mathrm{pH}$, hacim ağırlığı, faydalı su kapasitesi gibi indikatörlerin kalite sınıfı atamalarına etkisi daha iyi anlaşılabilir olacaktır. Bununla birlikte farklı indikatörlerin (örneğin; $\mathrm{CaCO}_{3}$, mikro besin elementleri, ağır metaller) indise kolaylıkla adapte edilebilir olması sayesinde faklı toprak özellikleri gösteren arazilerde yeniden kurgulanarak kullanılabileceği önerilebilir. Tüm bu değerlendirmeler ve katkılar ile indisin geliştirildiği bölge ekolojisini tümüyle temsil etmesi sağlanacaktır. 


\section{Teșekkür}

Bu çalışmada, TÜBİTAK tarafından desteklenen "1120487" No'lu projenin verilerinden yararlanılmıştır.

\section{Kaynaklar}

Ahmed, G.B., Shariff, A.R.M., Balasundram, S.K., Bin Abdullah, A.F., 2016. Agriculture land suitability analysis evaluation based multi criteria and GIS approach. In IOP Conference Series: Earth and Environmental Science, 37(1): 12-44

Akıncı, H., Özalp, A.Y., Turgut, B., 2013. Agricultural land use suitability analysis using GIS and AHP technique. Computers and Electronics in Agriculture, 97: 71-82.

Aldababseh, A., Temimi, M., Maghelal, P., Branch, O., Wulfmeyer, V., 2018. Multi-Criteria evaluation of irrigated agriculture suitability to achieve food security in an Arid environment. Sustainability, 10(3): 803.

Andrews, S.S., Karlen, D.L., Cambardella, C.A., 2004. The soil management assessment framework: A quantitative soil quality evaluation method. Science Society of America, 68(6): 1945-1962.

Anonim, 1982. Dalaman Tarım İşletmesi Topraklarının Detaylı Toprak Etüd ve Haritalanması. TİGEM Yayınları No: 4, Ankara.

Anonim, 2014. Fethiye ve Çevresinde İklim Koşulları. (http://www.fto.org.tr/DB Image/29/170/fethiyevec evresindeiklimkosullari.pdf), (Erişim tarihi: 16.10.2015).

Anonymous, 1976. A Framework for Land Evaluation. FAO Soils Bulletin Vol. 32, Food and Agriculture Organization, Rome.

Anonymous, 1990. Micronutrient, Assessment at the Country Level: An International Study. FAO Soil Bulletin by Mikko Sillanpaa. Rome.

Anonymous, 1999. Soil Taxonomy: A Basic System of Soil Classification for Making and Interpreting Soil Surveys. US Government Printing Office.

Anonymous, 2011. Soil Survey Laboratory Methods Manual: Soil Survey Investigations Report. Lincoln, NE.

Arshad, M.A., Martin, S., 2002. Identifying critical limits for soil quality indicators in agro-ecosystems. Ecosystems \& Environment, 88: 153-160.

Askari, M.S., Holden, N.M., 2014. Indices for quantative evaluation of soil quality under grassland management. Geoderma, 230: 131-142.

Baridón, J.E., Casas, R.R., 2014. Quality indicators in subtropical soils of formosa, Argentina: changes for agriculturization process. International Soil and Water Conservation Research, 2(4): 13-24.

Barraclough, P.B., 1989. Root growth, macro-nutrient uptake dynamics and soil fertility requirements of a high-yielding winter oilseed rape crop. Plant and Soil, 119: 59-70.
Bilgin, Z.R., Metin, Y., Çörekçioğlu, E., Bilgiç, T., Şan, Ö., 1997. Bozburun-Marmaris-Köyceğiz-Dalaman (Muğla) Dolayının Jeolojisi: MTA, Rapor No: 10008, Ankara.

Blake, G.R., Hartge, K.H. 1986. Bulk density. In: A. Klute (Ed), Methods of Soil Analysis. Part 1, Physical and Mineralogical Methods, Soil Science Society of America, Madison, pp. 363-376.

Bremner, J.M., Mulvaney, C.S. 1982. Nitrogen-Total. In: A.L. Page (Ed.), Methods of Soil Analysis, Part 2: Chemical and Microbiological Properties, American Society of Agronomy, Inc., and Soil Science Society of America, Inc., Madison, pp. 595-624.

Bydekerke, L., Van Ranst, E., Vanmechelen, L., Groenemans, R., 1998. Land suitability assessment for Cherimoya in Southern Ecuador using expert knowledge and GIS. Agriculture, Ecosystems \& Environment, 69(2): 89-98.

Ceballos S.A., López, B.J., 2003. Delineation of suitable areas for crops using a multi-criteria evaluation approach and land use/cover mapping: A case study in Central Mexico. Agricultural Systems, 77: 117136.

De La Rosa, D., Van Diepen, C.A., 2009. Qualitative and Quantitative Land Evaluations. In: W.H. Verheye (Ed.), Encyclopedia of Land Use, Land Cover and Soil Sciences-Volume II, Eolss Publishers, Oxford, United Kingdom.

Dengiz, O., 2019. Soil quality index for paddy fields based on standard scoring functions and weight allocation method. Archives of Agronomy and Soil Science, 1-15.

Dengiz, O., Baksan, O., 2009. Land quality assessment and sustainable land use in Salt Lake specially protected area. Journal of Environmental Monitoring and Assessment, 148(1-4): 233-243.

Dengiz, O., Özyazıc1, M.A., Sağlam, M., 2015. MultiCriteria assessment and geostatistical approach for determination of rice growing suitability sites in Gökırmak Catchment. Paddy Water Environment, 13(1): 1-10.

Dengiz, O., Özyazıcı, M.A., 2018. Çeltik tarımına uygun alanların belirlenmesinde çok kriterli arazi değerlendirme. Toprak Bilimi ve Bitki Besleme Dergisi, 6(1): 19-28.

Dengiz, O., Sarığlu, F.E., 2013. Parametric approach with linear combination technique in land evaluation studies. Journal of Agricultural Sciences, 19(2): 101112.

Dengiz, O., Şişman, A., Gülser, C., Şişman, Y., 2014. Alternative approach for land quality classification used for land consolidatin. Soil and Water Journal, 3(1): 59-69.

Doran, J.W., Parkin, T.B., 1996. Quantitative Indicators of Soil Quality: a Minimum Data Set. In: J.W. Doran, A.J. Jones, (Eds.), Methods for Assessing Soil Quality, Soil Science Society of America Special Publication, Madison, pp, 25-37.

Eastman, J.R., Jiang, H., 1996. Fuzzy Measures in MultiCriteria Evaluation. United States Department of 
Agriculture Forest Service General Technical Report RM, pp. 527-534.

Gezgin, S., Hamurcu, M., 2006. Bitki beslemede besin elementleri arasındaki etkileşimin önemi ve bor ile diğer besin elementleri arasındaki etkileşimler. Selcuk Journal of Agriculture and Food Sciences, 20(39): 24-31.

Guo, L.J., Zhang, Z.S., Wang, D.D., Li, C.F., Cao, C.G., 2015. Effects of short-term conservation management practices on soil organic carbon fractions and microbial community composition under a rice-wheat rotation system. Biology and Fertility of Soils, 51(1): 65-75.

Hazelton, P., Murphy, B., 2007. Interpreting Soil Test Results, What Do All the Numbers Mean. Commonwealth Scientific and Industrial Research Organization Publishing, Australia.

Huddleston, J.H., Pease, J.R., Forrest, W.G., Hickerson, H.J., Langridge, R.W., 1987. Use of agricultural land evaluation and site assessment in Linn County, Oregon, USA. Environmental Management, 11(3): 389-405.

Imaz, M.J., Virto,I., Bescansa,P., Enrique,A., Fernandez, A.O., Karlen, D.L., 2010. Soil quality indicator response to tillage and residue management on semiarid Mediterranean cropland. Soil and Tillage Research, 107(1): 17-25.

Iojă, C.I., Niţă, M.R., Vânău, G.O., Onose, D.A., Gavrilidis, A.A., 2014. Using multi-criteria analysis for the identification of spatial land-use conflicts in the Bucharest Metropolitan area. Ecological Indicators, 42: 112-121.

Jenks, G.F., 1967. The data model concept in statistical mapping. International Yearbook of Cartography, 7: 186-190.

Jiang, Z., Feng, C., Huang, L., Guo, W., Zhu, X., Peng, Y., 2006. Effects of phosphorus application on dry matter production and phosphorus uptake in wheat (Triticum aestivum L.). Plant Nutrition and Fertilizer Science, 26(5): 489-497.

Joshua J.K., Nneoma A.C., Jajere A, Ahmed A.J., 2013. Land suitability analysis for agricultural planning using GIS and multicriteria decision analysis approach in Greater Karu urban area, Nasarawa State Nigeria. African Journal of Agricultural Science and Technology, 1(1): 14-23.

Kacar, B., 2009. Toprak Analizleri (2. Bask1). Nobel Yayınları No: 1387, Ankara.

Karlen, D.L., Stott, D.E., Cambardella, C.A., Kremer, R.J., King, K.W., McCarty, G.W., 2014. Surface soil quality in five midwestern cropland conservation effects assessment project watersheds. Journal of Soil and Water Conservation, 69(5): 393-401.

Klute, A., 1986. Water Retention: Laboratory Methods. In: A. Klute (Ed), Methods of Soil Analysis. Part 1, Physical and Mineralogical Methods, Soil Science Society of America, Madison, pp. 635-662.

Kumar, T., Jhariya, D.C., 2015. Land quality index assessment for agricultural purpose using multicriteria decision analysis (MCDA). Geocarto International, 30(7): 822-841.
Kurzatkowski, D., Martius, C., Höfer, H., Garcia, M., Förster, B., Beck, L., Vlek, P., 2004. Litter decomposition, microbial biomass and activity of soil organisms in three agroforestry sites in Central Amazonia. Nutrient Cycling

Agroecosystems, 69(3): 257-267.

Laghari, G., Oad, F., Tunio, S., Gandahi, A., Siddiqui, M., Jagirani, A., Oad, S.M., 2010. Growth, yield and nutrient uptake of various wheat cultivars under different fertilizer regimes. Sarhad Journal of Agriculture, 26(4): 489-497.

Leonard, W.H., Stamp, D.L., Martin, J.H., 1976. Principles of Field Crop Production. Macmillan Publishing Company, New York.

Letey, J., 1958. Relationship Between Soil Physical Properties and Crop Production. Advances in Soil Science Book Series, Springer, New York.

Lindsay, W.L., Norvell, W.A., 1978. Development of a DTPA soil test for zinc, iron, manganese, and copper. Soil Science Society of American Journal, 42(3): 421428.

Malczewski, J., 2006. Ordered weighted averaging with fuzzy quantifiers: gis-based multicriteria evaluation for land-use suitability analysis. International Journal of Applied Earth Observation and Geoinformation, 8(4): 270-277.

Mandere, N.M., Persson, A., Anderberg, S., Pilesjö, P., 2010. Tropical sugar beet land evaluation scheme: Development, validation and application under Kenyan Conditions. GeoJournal, 75(2): 215-228.

Marschner, H., Kirkby, E. A., Cakmak, I., 1996. Effect of mineral nutritional status on shoot-root partitioning of photoassimilates and cycling of mineral nutrients. Journal of Experimental Botany, 47(Special Issue): 1255-1263.

McVay, K., Radcliffe, D., Hargrove, W.L., 1989. Winter legume effects on soil properties and nitrogen fertilizer requirements. Soil Science Society of America Journal, 53(6): 1856-1862.

Miller, F., Guthrie, R.L., 1984. Classification and Distribution of Soils Containing Rock Fragments in the United States. Erosion and Productivity of Soils Containing Rock Fragments, Soil Science Society of America Publishing, Madison, pp. 1-6.

Miransari, M., Smith, D.L., 2007. Overcoming the stressful effects of salinity and acidity on soybean nodulation and yields using signal molecule genistein under field conditions. Journal of Plant Nutrition, 30(12): 1967-1992.

Mueller, L., Schindler, U., Mirschel, W., Shepherd, T.G., Ball, B.C., Helming, K., Rogasik, J., Eulenstein, F., Wiggering, H., 2010. Assessing the productivity function of soils, A review. Agronomy for Sustainable Development, 30(3): 601-614.

Mustafa, S.M.T., Vanuytrecht, E., Huysmans, M., 2017. Combined deficit irrigation and soil fertility management on different soil textures to improve wheat yield in drought-prone Bangladesh. Agricultural Water Management, 191: 124-137.

Nelson, D.W., Sommers, L., 1982. Total Carbon, Organic Carbon, and Organic Matter. In: A.L. Page (Ed.), 
Methods of Soil Analysis, Part 2: Chemical and Microbiological Properties, American Society of Agronomy, Inc., and Soil Science Society of America, Inc., Madison, pp. 539-579.

Olsen, S.R., Sommers, L.E., 1982. Soil Phosphorus. In: A.L. Page (Ed.), Methods of Soil Analysis, Part 2: Chemical and Microbiological Properties, American Society of Agronomy, Inc., and Soil Science Society of America, Inc., Madison, pp. 403-430.

Pagliai, M., Vignozzi, N., Pellegrini, S., 2004. Soil structure and the effect of management practices. Soil and Tillage Research, 79(2): 131-143.

Patrono, A., 1998. Multi-Criteria Analysis and Geographic Information Systems: Analysis of Natural Areas and Ecological Distributions. Multicriteria Analysis for Land-Use Management. In: Beinat E., Peter N (Eds.), Environment and Management, Kluwer Academic Publishers, The Netherlands, pp. 271- 292.

Rahmanipour, F., Marzaioli, R., Bahrami, H.A., Fereidouni, Z., Bandarabadi, S.R., 2014. Assessment of soil quality indices in agricultural lands of Qazvin Province, Iran. Ecological Indicators, 40: 19-26.

Riley, H., Pommeresche, R., Eltun, R., Hansen, S., Korsaeth, A., 2008. Soil structure, organic matter and earthworm activity in a comparison of cropping systems with contrasting tillage, rotations, fertilizer levels and manure use agriculture. Ecosystems \& Environment, 124(3-4): 275-284.

Romano, G., Dal Sasso, P., Trisorio Liuzzi, G., Gentile, F., 2015. Multi-criteria decision analysis for land suitability mapping in a rural area of Southern Italy. Land Use Policy, 48: 131-143.

Saaty, T.L., 1980. The Analytical Hierarchy Process, Planning, Priority. Resource Allocation: RWS Publications, USA.

Saaty, T.L., 2008. Decision making with the analytic hierarchy process. International Journal of Services Sciences, 1(1): 83-98.

Sarkar, A., Ghosh, A., Banik, P., 2014. Multi-criteria land evaluation for suitability analysis of wheat: A case study of a watershed in eastern plateau region, India. Geo-Spatial Information Science, 17(2): 119-128.

Sauer, T., Havlík, P., Schneider, U.A., Schmid, E., Kindermann, G., Obersteiner, M., 2010. Agriculture and Resource availability in a changing world: The role of irrigation. Water Resources Research, 46(6): $1-12$.

Shepherd, T.G., 2009. Visual Soil Assessment: Field Guide for Pastoral Grazing and Cropping on Flat to Rolling Country. Horizons Regional Council, Palmerston North, New Zealand.

Siegel, S.M., Siegel, B.Z., Massey, J., Lahne, P., Chen, J., 1980. Growth of corn in saline waters. Physiologia Plantarum, 50(1): 71-73.

Store, R., Kangas, J., 2001. Integrating spatial multicriteria evaluation and expert knowledge for GISbased habitat suitability modelling. Landscape and Urban Planning, 55(2): 79-93.

Şeker, C., Işıldar, A., 2000. Tarla trafiğinin toprak profilindeki gözenekliliğe ve sıkıșmaya etkisi. Turkish Journal of Agriculture and Forestry, 24: 7177.

Topal, A., Gezgin, S., Akgün, N., Dursun, N., Babaoglu, M., 2002. Yield and Yield Attributes of Durum Wheat (Triticum durum Desf.) as Affected by Boron Application. In: Goldbach et al. (Eds.), Boron in Plant and Animal Nutrition, Springer, Boston, MA., pp. 401-406.

Veisi, H., Liaghati, H., Alipour, A., 2016. Developing an ethics-based approach to indicators of sustainable agriculture using analytic hierarchy process (AHP). Ecological Indicators, 60: 644-654.

Xue, R., Wang, C., Liu, M., Zhang, D., Li, K., Li, N. 2019. A new method for soil health assessment based on analytic hierarchy process and metaanalysis. Science of The Total Environment, 650: 2771-2777.

Ying, X., Zeng, G. M., Chen, G. Q., Tang, L., Wang, K L., \& Huang, D. Y., 2007. Combining AHP with GIS in synthetic evaluation of eco-environment quality-A case study of Hunan Province, China. Ecological Modelling, 209(2-4): 97-109.

Zhan, A., Zou, C., Ye, Y., Liu, Z., Cui, Z., Chen, X., 2016. Estimating on-farm wheat yield response to potassium and potassium uptake requirement in China. Field Crops Research, 191: 13-19.

Zhang, J., Su, Y., Wu, J., Liang, H., 2015. GIS based land suitability assessment for tobacco production using ahp and fuzzy set in Shandong Province of China. Computers and Electronics in Agriculture, 114: 202211. 